\title{
ДОСВІД ЛОКАЛЬНОЇ ІДЕНТИЧНОСТІ
}

\author{
ЯРОСЛАВ ПОЛІЩУК \\ Університет імені Адама Міцкевича, Познань - Польща \\ yaropk@gmail.com \\ DOŚWIADCZENIE TOŻSAMOŚCI LOKALNEJ \\ JAROSŁAW POLISZCZUK \\ Uniwersytet imienia Adama Mickiewicza, Poznań — Polska
}

STRESZCZENIE. Autor rozpatruje kulturowy wizerunek Donbasu na przykładzie współczesnej literatury ukraińskiej, zwłaszcza w powieści Ołeksija Czupy Bajki mojego bunkra (2014). Badanie donieckiej tożsamości jest trudne z powodu niewystarczającej reprezentacji w tekstach współczesnej kultury, a także za sprawą demonizacji regionu w okresie aktualnej wojny na Wschodzie Ukrainy. Bohaterowie powieści Czupy to typowi mieszkańcy Donbasu, "szarzy" ludzie, stąd w ich zachowaniu bardzo ważne wydaje się przeżywanie doznań cielesnych. Donieckie doświadczenie cielesności apeluje zarówno do sytuacji egzystencjalnej, co powoduje przewartościowanie zasad moralnych, jak i do kształtowania nowej formuły jednostki jako fenomenu społecznego.

\section{EXPERIENCE OF LOCAL IDENTITY}

\author{
YAROSLAV POLISHCHUK \\ Adam Mickiewicz University, Poznan — Poland
}

ABSTRACT. In the article the cultural reflection of the physicality of Donbass has been researched. As the example of such question's description in the contemporary literature the author chose Oleksiy Chupa's novel The Tales of My Shelter (Казки мого бомбосховища, 2014). The problem of the researching of Donetsk's identity consists in the very fact that there is no clear manifestation of it in the modern culture. The heroes of the researched novel are typical inhabitants of Donbass: the "grey" people for whom primitive customs and physical needs are the most important and very often just hidden. Donetsk's experience of physicality, as the novel of Oleksiy Chupa shows, appeals to the typical existential situation which is accompanied by the revision of cultural values and very often leads to the social matrix changing of the perception of a human.

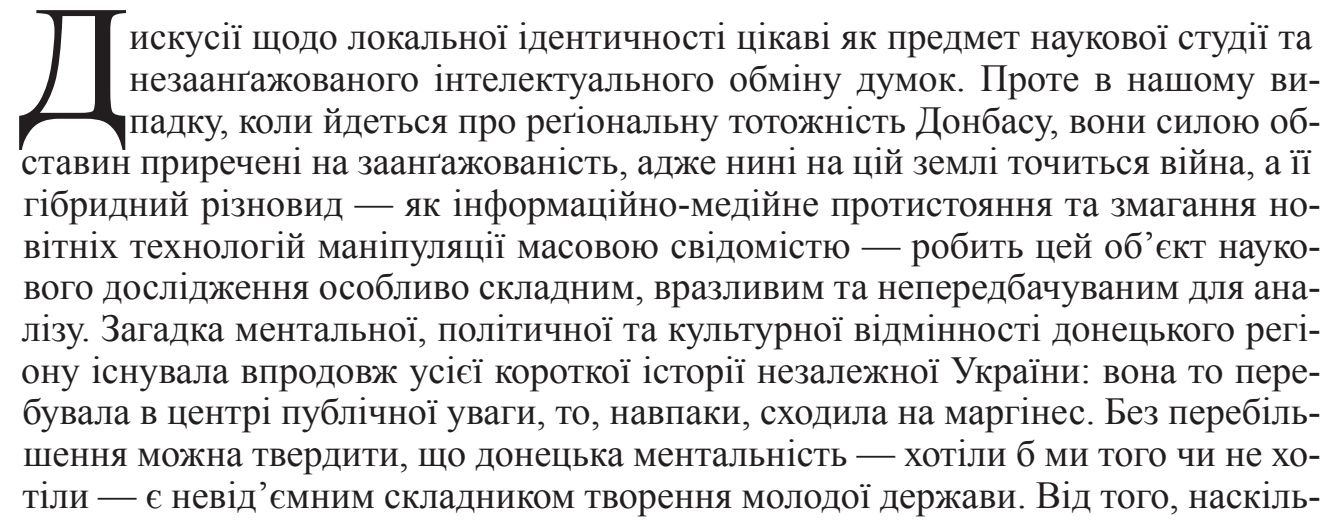


ки вона виразна й наскільки поєднується з іншими регіональними тотожностями України, залежить успіх самої країни загалом.

У нинішніх умовах донецька проблема стала найбільш виразним проявом ідентичнісної кризи, яку переживає посткомуністична Україна. Про цю кризу із занепокоєнням говорять українські інтелектуали, як-от Микола Рябчук ${ }^{1}$, Ярослав Грицак ${ }^{2}$, Оксана Забужко ${ }^{3}$ та ін. ${ }^{4}$, причому проблему вони порушували ще задовго до воєнного конфлікту на Сході України. В останні роки нових аргументів, по суті, не додалося, хіба що загострилися у своєму звучанні старі. Так, відверте обговорення стану внутрішньої роз'єднаності в актуальних умовах наражається на критику не тільки конструктивну, а й деструктивну, оскільки воно може бути легко використане для очорнення образу України поза її кордонами. У реаліях гібридної інформаційної війни стало „загалом характерно подавати Україну як пасивний об'єкт, а не суб'єкт історії, - такого собі пішака на світовій шахівниці, безрадну жертву глобальних гравців...”5.

Проте постановка подібних складних питань незмінно лежить на відповідальності інтелектуалів. Можна зауважити певну тенденцію: на тлі загалом активного культурно-інтелектуального ринку Донбас досі виглядав і далі виглядає (тепер уже з цілком об'єктивних причин ізольованості й воєнного конфлікту) своєрідною сірою зоною. Це сприяє тому, що край надалі зберігає за собою флер таємничості та непередбачуваності, який вирізняв його й раніше, а сьогодні, в умовах фізичної й недійної ізоляції, може перетворитися в нездоланний бар'єр. Війна, яка триває на території двох східних областей України, що й становлять промисловий регіон Донбасу, загострила увагу до межових емоцій та відчуттів людини. Звичайно, мешканці цього краю переживають біль, страх, загубленість, депресію. Це стає - i на індивідуальному, й на колективному рівнях - новим досвідом, що здатен спонукати до переосмислення проблеми тілесності: від іiі біологічного сенсу до соціального, від емоційного сприйняття до інтелектуальної рефлексії.

Мабуть, одним із ключових чинників триваючої кризи локальної ідентичності Донбасу слід визнати брак традиції, який зумовлює розгубленість, дезорієнтованість та непослідовність мешканців регіону у прийнятті важливих рішень. Відсутність традиції, що продиктована об'єктивними причинами минулого (про що мова буде ще далі), породжує страх і непевність у сприйнятті нинішньої ситуації. Авторитетні західні дослідники твердять: „Niezależnie od tego, czy indywidualna, czy zbiorowa, tożsamość zakłada [...] nieustanny proces odtwarzania i reinterpretacji. Tożsamość to stworzenie niezmienności w czasie, zbudowa-

1 М. Рябчук віддавна звертав увагу на суспільну амбівалентність, коли в Україні культивувались взаємно суперечливі цінності, що було джерелом постійного конфліктного напруження, тобто властиву “постсовєтську шизофренію”. Див. його праці: М. Рябчук, Дві України. Реальні межі, віртуальні війни, Київ 2003, с. 33-38. Також у польському перекладі: M.Ri abczuk, Dwie Ukrainy, tłum. z ukr., Wrocław 2005, s. 16-18.

2 Я. Грицак, Страсті за наиіоналізмом. Стара історія на новий лад, 2-е вид., Київ 2011, c. $53-64$.

${ }^{3}$ О. З Забужкко, „I знов я влізаю в танк...”. Вибрані тексти 2012-2016: статті, есе, інтерв’ю, спогади, Київ 2016.

${ }^{4}$ Акценти пам'яттєвого дискурсу наголошує в ситуації кризи Алла Киридон. Див.: А. Ки р и дон, Гетеротопії пам'яті. Теоретико-методологічні проблеми студій пам'яті, Київ 2016. Переклад іiї публікації на цю тему польською мовою див.: А. Kyrydon, Wyzwania tożsamości narodowej w warunkach nowoczesnego kryzysu ukraińskiej państwowości, [w:] „Kultura — Historia — Globalizacja" 2010, nr 8, s. 101-109.

5 М. Рябчук, Випробування війною, [в:] Електронний ресурс: http://www.ji-magazine.lviv. ua/2016/Ryabchuk_Vyprobovannya_Ukrainoyu.htm (21.01.2017). 
nie łączności między przeszłością a przewidywaną przyszłością. We wszystkich społeczeństwach utrzymanie jednostkowej tożsamości i połączenie jej z szerszymi tożsamościami społecznymi służy jako podstawowe narzędzie zapewnienia bezpieczeństwa ontologicznego. Niepokój psychologiczny to jedna z głównych sił pozwalających tradycji na wytworzenie tak silnych więzów emocjonalnych po stronie «wierzącego». Częste, jeśli nie powszechne zagrożenia dla integralności tradycji doświadczane są jako zagrożenia dla integralności «ja»" ${ }^{6}$.

Уважають, що існує три способи задоволення наших тілесних бажань пригнічення, утолення й підсилення7. Перший схиляє людину до аскетизму, коли вона обмежує свої потреби й підпорядковує їх чомусь, що вважає важливішим. Другий випадок веде до гедонізму: саме він добре описаний 3. Бауманом як синдром постмодерного тіла ${ }^{8}$, що не може стриматися в колекціонуванні бажань. Зате третій передбачає досягнення продуктивного та креативного рівня порозуміння з власним тілом. За такої умови ми вчимося „вирощувати й пестити свої бажання [...], але використовувати їх енергію для творчих досягнень" .

Замислюючись над тілесністю по-донецьки, маємо взяти до уваги кілька обставин, що дуже утруднюють дослідження цього предмету. Це, по-перше, відносно слабка проявленість у текстах культури, зокрема, коли йдеться про художню літературу. Сьогодні небагато знайдеться письменників, що не тільки походженням пов'язані $з$ Донбасом, а й уважають цей регіон основним об’єктом свого художнього зображення (О. Стяжкіна, В. Рафєєнко, О. Чупа, О. Соловей та ін.). Це, до речі, пояснює наш вибір текстів для ілюстрації - він не $\epsilon$ ідеальним, але цей вибір відповідає злобі дня. По-друге, специфіка донецької регіональної ідентичності нерідко формується під впливом крайнощів ії сприйняття. По-третє, маємо справу зі зрощенням індивідуальної тотожності 3 колективною, неемансипованою індивідуальною свідомістю, що надзвичайно ускладнює можливість диференціації цих двох чинників (зокрема і в цій статті). Ще донедавна в публічному дискурсі всіляко акцентувалася винятковість “донецьких", причому в позитивному значенні слова. Нині ж, навпаки, вона опинилася під міцним пресом негативного стереотипу, що ускладнює об'єктивне розуміння предмету дослідження. Подолання конфлікту не видно, як не видно 3 жодного боку бажання оцінити його нелінійно, у всій складності. На цьому тлі письменники діагностують ситуацію нестандартно, прагнуть 3 розумінням сприйняти рацію різних сторін конфлікту. Їх найбільше хвилює гуманітарний вимір проблеми, себто доля звичайних мешканців Сходу, які легко піддаються маніпуляціям та зраджують ментальність homo sovieticus. Саме в цьому аспекті непримиренність $є$ принциповою i, швидше за все, не може бути подолана відносно швидко та безболісно. Вона має всі шанси перерости в хронічну хворобу осяжного українського майбутнього, про що Сергій Жадан відверто свідчить: „Як далі жити з тими, хто підтримує сьогодні самопроголошені республіки, не уявляю. Бачу з того боку тотальне неприйняття, агресію. Складно уявити, що ці люди завтра знову зможуть святкувати одні свята, слухати вітання одного президента, їздити в одному транспорті й сидіти в одних кафе 3 людьми, які були по інший бік фронту. Якщо моделювати ситуацію - настає перемир'я,

${ }^{6}$ Ulrich Beck, Anthony Giddens, Scott Lash, Modernizacja refleksyjna: polity$k a$, tradycja $i$ estetyka $w$ porzadku społecznym nowoczesności, przetł. Jac e k Konie c zny, Warszawa 2009 , s. 109.

${ }^{7}$ М. Эпш тей н, Философия тела, Санкт-Петербург 2006, с. 111.

${ }^{8} \mathrm{Z}$. B a um an, Ciało i przemoc w obliczu ponowoczesności, Torun 1995.

${ }^{9}$ М. Эпштейн, Философия тела..., с. 111. 
досягається компроміс, скажімо, із розширеними правами для цих територій. Сотні тисяч донеччан і луганчан, що звідти виїхали, - туди повернуться? Знаю багатьох, які кажуть: «Я з цими людьми жити не хочу». А якщо повернуться, то як до них ставитимуться? Якщо ти ціле літо просидів під обстрілами, а хтось поїхав, $є$ велика ймовірність, що ти до цієї людини ставитимешся, як до зрадника, який покинув своє місто" 10 .

До людського виміру цієї війни ще будемо не раз повертатися. I ревізію морально-етичних цінностей мешканців регіону ще буде проведено - не без колізій, самокритики й самокаяття. Поки ж не випадає про це говорити 3 достатньою аргументацією, якщо опиратися на матеріал художньої літератури. Проте перші спроби рефлексії Донбасу, його складної еволюції від учорашнього регіону-фаворита до ізгоя, наяву. Це зокрема оповідання та романи Олексія Чупи ${ }^{11}$. Один 3 його недавніх творів у цій статті вибрано для аналізу, хоча він не $\epsilon$ бездоганним з естетичного погляду. Проте нас цікавитиме передусім його, сказати б, референтна фактурність - те, як у творі зображено реалії життя й побуту, а також почуття й самосвідомість героїв, що репрезентують сучасний Донбас. Спостереження такого штибу наближатимуть нас до розуміння специфічності донецької ідентичності - у тому значенні, у якому вона проявляється в сучасній культурі. Утім, не випадало б заперечувати поверховість цих спостережень, оскільки ментальність мешканців Донбасу, саме з огляду на кардинальні трансформації, що тривають у регіоні, — також підлягає гвалтовним змінам, вона переживає шоковий стан і час радикальної переорієнтації.

Олексій Чупа - корінний донеччанин, який добре знає людей та життєві реалії свого регіону, перебуваючи там від народження (до війни він мешкав у Макіївці). Він спостерігає те все не поглядом гостя, а свідка й учасника дійства. Недаремно анотації роману Казки мого бомбосховища (2015) починають власне з такої інформації. Але твір Олексія Чупи цікавий і особливий тим, що $\epsilon$ спробою створення колективного портрету “донецьких”. Адже нечасто вони ставали героями новітньої української літератури. Якщо пропустити повз увагу соцреалістичні часи 3 нудними виробничими романами, що так і списувались у макулатуру непрочитаними, та й скоро забулися начисто, то в останні часи згадувати буде майже нічого. За винятком кількох творів Сергія Жадана, Олега Солов'я та ще кількох менш знаних авторів, густозаселений до недавніх пір Донбас в українській літературі лишався відносною цілиною. Хтось же таки мусив заходитися до оранки цих перелогів. От молодий автор і нагодився, а його книжкова пропозиція виявилася дуже навіть до речі в умовах гострого інформаційного голоду щодо Сходу України. Бо й тепер, коли там палає земля, говорять в основному таки про війну, про її перебіг та сили супротивників, а от стан і переживання місцевого населення - то тема мало знана й мало акцентована. Звісно, у художній літературі (на відміну від публіцистики, яка жвавіша й відвертіша), що досі лишається в нас на диво цнотливою, уперто цураючись тем актуальних і гарячих.

${ }^{10}$ С. Жадан, 3 одного боку, нам потрібні “Макдональдзи”, з іншого - пам'ятники Леніну, [в:] „Газета по-українськи” 2015, 3 березня, [в:] Електронний ресурс: http://gazeta.ua/articles/people-and-things-journal/_z-odnogo-boku-nam-potribni-makdonaldzi-z-inshogo-pamyatnikileninu/613092 (22.01.2017).

${ }^{11}$ Олексій Чупа - український поет і прозаїк, родом з Макіївки. У літературі став відомим завдяки трьом книжкам художньої прози, що з'явилися друком в одночассі, до того ж, збіглися 3 трагічними подіями на Донбасі. Це книги оповідань і повістей 10 слів про Вітчизну (2014), Бомжі Донбасу (2014), Казки мого бомбосховища (2015). Пізніше також видав романи Акваріум (2016), Вишня і я (2016). 
Олексій Чупа вчиться “чути Донбас" не в тому спекулятивному значенні, яке надають цьому слоганові політики, а в глибшому сенсі самоідентичності краян. Він хоче збагнути їхню сутність, чи то в благородних поривах, чи то в низьких інстинктах або моральному убозтві. При цьому прагне уникати крайнощів. 3 одного боку, молодий автор сторониться поверхово-патріотичного пафосу, зображує життя досить критично: відчувається, що зміна епох навчила його скептично ставитися до всякого поверхового пафосу. Звідси в романі жорсткий реалізм, що межує з натуралізмом. 3 іншого боку, автор усе-таки не зрікається романтичного уявлення про людину, а тому прагне знайти щось хороше, добре, заповітне в кожному зі своїх персонажів. Нерідко робить це наївно, та все ж щиро. І в цьому його оповідь про мешканців Донбасу видається колоритною й повновартісною, на відміну від репортажів та фельєтонів, у яких зазвичай домінує поверхове чорно-біле сприйняття людей та подій. Про сучасний Донбас, розорений і пригноблений війною, у середовищі інтелектуалів слушно говорять як про місце гуманітарної катастрофи. Це насправді дуже складний і занедбаний регіон, а тривалі, ще з радянських часів, маніпуляції зі свідомістю його мешканців привели до слабко зазначеної, роздвоєної, депресивної, схильної до ресентименту, ідентичності. Варто нагадати, що на початку 2000-х соціологи помітили прикметну тенденцію. Коли під час перепису населення думки щодо національності розходились, то значна частина, не бажаючи асоціювати себе ані з росіянами (що цілком домінують і нетерпимі щодо інших), ані 3 українцями (що упосліджені на Сході України), указувала етнічну приналежність як "совєтські"

Звісно, це логічний наслідок і релікт радянського культу Донбасу. Колись же пропаганда захмарно підносила цей регіон, вирізняючи шахтарів як еліту пролетаріату (що, варто зазначити, мало підтвердження і в матеріальному вимірі) та вважаючи край мало не зразковим осередком соціалістичного побуту. Насправді все виглядало, однак, зовсім не райдужно. На мільйони робітників припадало надто мало інтелігенції, центрів освіти й культури, а високі статки місцевого населення здебільшого так і не конвертувалися в добробут, бо значна частина їх підживлювала алкоголізм, наркоманію, проституцію та інші суспільні пороки. Така спадщина радянського минулого дісталася Україні після 1991 року. Але й в останні десятиліття Донбас розвивався надто мляво. Прихід до влади мафіозних груп, які зуміли швидко згребти мільярди на приватизації державних підприємств, нічого доброго не приніс звичайним громадянам. Ïх ще глибше загнали в стан злиденності, безправ'я та рабського послуху. Піком могутності донецької мафії стало обрання президентом Віктора Януковича - від цього моменту “донецькі”, ніби спрут, душили всю Україну. Існує думка, що період правління Януковича був часом нав'язування цілій країні регіональної моделі розвитку - "України донбаського виробництва"13, причому настільки брутальним та неприйнятним, що вже від початку викликав у суспільстві гострий осуд, а згодом і повзучий, проте невпинно наростаючий, спротив. Тільки через Революцію гідності зими 2013-2014 років українці домоглися відсторонення від влади донецьких олігархів. Але ж їхні впливи досі лишаються сильними: в економіці, фінансовій сфері, місцевих органах влади тощо.

Донецький дискурс нерегламентованої влади, насильства, крутійства, з одного боку, та впокорення, приниження й мовчання, з іншого, є вже традицією.

\footnotetext{
${ }^{12}$ Я. Грицак, Страсті за начіоналізмом..., с. 50.

${ }^{13}$ Там само, с. 310.
} 
На початку 2000-х років у видавництві “Основи” вийшла друком в українському перекладі цікава праця американського вченого японського походження Гіроакі Куромії Свобода і терор в Донбасі (2002). Тоді вона майже не була помічена науковою громадськістю, а нині, у контексті актуальних подій, випадало би повернутися до суджень та висновків цього західного історика. Він, між іншим, стверджує, що ще 3 часів перших промислових розробок вугілля в регіоні тривало протистояння поміж буржуазією (власниками) та робітниками (шахтарями). Так, британська компанія Джона Г'юза (це на його честь Донецьк колись дістав назву Юзівки), намагаючись погасити протести робітників з приводу підвищення оплати праці, удавалась не тільки до репресивних заходів, як-от збройне придушення опору, а й — не менш успішно — до підкупу та шантажу. Так, під час заворушення 1874 року адміністрація споїла горілкою частину робітників, налаштовуючи їх супроти іншої, чорноробів, і так удалося успішно нейтралізувати протестні настрої в середовищі шахтарів ${ }^{14}$. Очевидна річ, російська та радянська влада не менш успішно застосовувала такі методи, унаслідок і сформувалася особлива модель стосунків власті імущих та роботяг. 3 одного боку, необмежена влада, що межує зі сваволею, підкупом, махінаціями; з іншого ж, необмежена покірність, вихована зневірою в досягнення справедливості. Як на цьому тлі оцінювати соціальні блага, задекларовані щодо мешканців краю в період СРСР? Певною мірою вони були вдалою риторикою влади, адже рекламували принципи справедливості й поступу. Проте не надто підтверджувалися суспільною практикою, яка в життєвій практиці їх здебільшого не дотримувалася.

Феномен Донбасу полягає, між іншим, у радикальній відмінності поміж бізнес-елітою та пересічними громадянами. Така дивовижна специфіка регіону, що географічно локується в межах України, зате ментально перебуває десь поза рамцями актуального часопростору, прагне кудись у вже давно не існуюче минуле та безнадійно ностальгує по ньому. Точніше, тужить за солодкими атрибутами минувшини - державним патерналізмом, щедрою соціальною допомогою тощо. Внутрішні (соціальні, демографічні, етичні, конфесійні) конфлікти Донбасу можна уявити як рівночасне існування кількох дискурсів, не сумісних поміж собою. Донецька бізнес-еліта, яка досі, головно, формувала образ регіону, цілком непогано почувалася в умовах постмодерну й стала виразником світу постмодерного гедонізму. Постмодерне тіло, за 3. Бауманом, є насамперед сприймачем вражень, які воно охоче колекціонує. Таке тіло налаштовує людину на пошук усього, що справляє приємність: воно зазнає сексуальних, гастрономічних, слухових, візуальних та ін. приємних відчуттів. Постійно вбираючи такі відчуття, постмодерне тіло стає залежним від них, воно все більше й більше перетворюється на інструмент діставання приємних вражень, без будь-яких обмежень, зате 3 наростаючою силою й енергією ${ }^{15}$. 3 іншого боку, серед донецького населення виявилося більшість таких, хто не має задоволених елементарних життєвих потреб. Саме вони сьогодні становлять ту частину населення, яка найбільше потерпає в актуальних умовах війни. На відміну від місцевих “мажорів", що сповідували постмодерну філософію тілесності, такі люди засвідчують радше домодерну тілесність, оскільки наражаються на типові обмеження та страждання - брак їжі й води, тепла й житла, задовільних побутових

\footnotetext{
${ }^{14}$ Г. Куромія, Свобода і терор в Донбасі. Украӥнсько-російське прикордоння. 1870-1990mі роки, пер. з англ. Г. Кь оран, В. Агеєв, передмова Г. Нем ирі, Київ 2002, с. 87.

${ }^{15} \mathrm{Z}$. B a uma n, ibidem, s. 90-91.
} 
умов. Разюча відмінність між розумінням тіла як інструменту насолод та тіла як засобу виживання (при тому, що ці дві кондиції можуть 3 огляду на обставини бути замінені місцями) - це чергова серйозна тема для рефлексій.

Попередньо викладений екскурс у реалієзнавство Донбасу був необхідний для того, щоби з'ясувати сутність актуальних процесів та подивитися, як же вони відображені в новому романі О. Чупи, що про нього тут мовиться. Отож, автор принципово обирає за об' єкт свого творчого аналізу пересічний, “сірий” Донбас. Його герої - звичайні люди з притаманними їм пристрастями, що нерідко ведуть слизькими дорогами до страждань, агресії, насильства та злочинів. За кожним оповіданням стоїть певна доля, зазвичай непроста, поламана, скалічена. Хоча автор не акцентує на цьому спеціально, проте досить було б уважно придивитися до сутності цих людей, щоби виявити в їхніх характерах давні й замовчувані, нікому не сповідувані, травми. Адже в кожному житті було закладено благородний потенціал, інша справа — що із цього проросло та чим обернулося в понурому оточенні деморалізованої донецької глибинки.

Умови гібридної війни та гібридної реальності, що іiї супроводжує, породжують нові конфігурації суспільної етики. Це той випадок, який свого часу описував видатний соціолог і філософ 3. Бауман: сучасність сприяє занепаду традиційного розуміння моралі й моральних заповідей, натомість тілесні рефлексії нерідко визначають нашу поведінку, звільнену від умовностей релігії та давніх поведінкових табу. Учений пропонував також відповідь на непросте питання втрати чутливості та співчуття в межовому стані людини. Осмислюючи феномен зла й насильства, що найгостріше виявився в масових злочинах нашої епохи, він, однак, полемізує з Г. Арендт у виявленні причин порочного суспільного явища. 3. Бауман пише, що корінь зла належить убачати не в нерозумінні, а в нечутливості, коли окремо взята людина відмовляється подолати сконструйовані суспільством форми та стереотипи, прорватися крізь них: таким чином, вона спілкується зі штучною маскою, а не з обличчям і не зупиняється перед злочином, виправдовуючи себе за допомогою соціально адаптованих стереотипів ${ }^{16}$.

Проблема тілесності своєрідно відтіняє наші уявлення про суспільний устрій та його пріоритети. Існує традиційне (і сильно гіперболізоване, скажемо одразу) уявлення про те, що тіло, на відміну від думок чи почуттів, $є$ територією індивідуалізованою та інтимізованою, тому відчитування мови тіла вважається непростим і дуже ризикованим заняттям. Таке упередження руйнує згаданий вище вчений, стверджуючи, що тіло може й повинно підлягати інтерпретуванню на рівні суспільних механізмів контролю. Він зокрема пише, „a co, jeśli przyjąć, że ciało ludzkie, podobnie jak myśli i uczucia, jest wystawione na działania społeczeństwa? Że na ciele, podobnie jak na myślach i uczuciach, społeczeństwo odciska swój kształt [...], że ciało podobnie jak myśli i uczucia, jest wytworem społecznym, $\mathrm{i}$ «sens bycia wytworem» ma swą historię w przypadku ciała podobnie jak ma ją w przypadku myśli i uczuć"17.

У романі О. Чупи відчувається не тільки добре знання реалій, а й розуміння конкретних людських мотивацій поведінки. Недаремно ж у рукописі зазначено дві дати написання роману - “30.08.1986 - 20.08.2014”. Цей час визначає період знайомства $з$ персонажами твору. Точніше, спочатку це було знайомство 3 сусідами та близькими, тому що сам автор родом з Макіївки, типового робіт-

\footnotetext{
${ }^{16}$ Tamże, s. 60-61.

${ }^{17}$ Tamże, s. 70.
} 
ничого міста донецького регіону, і до 2014 року, коли почалася війна та змусила до евакуації, незмінно жив у цьому місці. Жив у оточенні людей, образи яких відтворив у новому романі. Подієва основа роману досить скромна і схематична; явно невідповідна до формату роману, радше - циклу оповідань, пов'язаних між собою спільністю місця дії й часу. Вона яскраво проявляється лише в деяких епізодах: в озброєному зіткненні на порозі квартири Вєрки Лабуги (розділ Секс утрьох) або в спробі повалення пам'ятника (розділ Good Bye, Lenin!). У цьому сенсі твір не претендує на статус серйозної епіки, а його сюжетний план доволі статичний та конспективний. Автор, проте, не так переймається подієвим планом оповідання, як психологічною характеристикою персонажів: йому важливо створити своєрідну галерею, де кожен був би впізнаваним і не схожим на інших. Адже, узяті у своїй множинності, ці персонажі репрезентують властиву спільноту, місто, край. При цьому спільнота не $є$ стійкою: саме так характеризував сучасну спільноту М. Бланшо, розуміючи як відносне та пливке утворення ${ }^{18}$. У такий спосіб О. Чупа прагне вивести колективний образ своєї батьківщини з тіні традиційної непроявленості та сіризни, наповнивши його живим, колоритним змістом. Якщо й потрібні авторові Казок мого бомбосховища фабульні зв'язки, то заради цього, щоби повніше й рельєфніше представити характери героїв, їхні причинно-наслідкові зумовленості. I хоча назовні портрети окремих персонажів виглядають статичними, то завдяки прийомам внутрішнього монологу, коли передаються думки та відчуття героїв, вони набувають належної повноти та завершеності.

При цьому О. Чупа намагається зберегти нейтральність стороннього спостерігача. Прикметно, що він не стає в позу моралізатора: уважно спостерігає, прагнучи знайти логіку в думках і вчинках людей, а також відкрити для читача світ їхніх почуттів, мрій, страждань і переживань. Іноді це вдається краще, як-от у розділах Сни та інші речі, Острів, Квіткарка Ру, інколи гірше. Так, у першому з названих прозаїк спробував змоделювати суперечливу істоту бійця спецзагону "Беркут" Бембі - людини-зомбі, сліпого виконавця. Саме такі, як Бембі, восени та взимку 2013 й 2014 року шокували українське суспільство своєю брутальністю, звірством та цинізмом. Автор “сканує” свідомість персонажа за допомогою концепту страху. Бембі не сприймає світ критично, не обтяжує себе зайвими думками; він типовий виконавець і для нього більш важливі маркери авторитетності. Це той тип людини-функції, який свого часу досконало описала Ганна Арендт у постаті виконавців гітлерівської політики Голокосту $^{19}$. Проте разом з виконанням бездушних наказів у свідомості героя наростає панічний страх перед можливим покаранням: спершу проявляється в його сновидіннях та кошмарах, а затим нав'язливо переслідує скрізь, доводячи до повної внутрішньої кризи: „Прокидатися роздертим - значить не прокидатися зовсім. Значить жити в передчутті жахіття, боятися, чи не прогавив ти момент, коли воно почалося. Бембі згадував минулі кілька років роботи, згадував побитих ним і переконувався, що своєю смертю він не помре"20.

Автор роману ніби колекціонує долі різних людей: колишньої коханки прокурора, ледащиці Вєрки Лабуги, нещасливої родини учених-філологів Задорожних, пенсіонерки Клави з прогресуючою хворобою глухоти, недолюбленого хлопчика Владика, молодіжних груп Фірмана або сатаністів із Саньком Піді-

${ }^{18}$ М. Бл анш о, Неописуемое сообщество, пер. Ю.С т е фан о в а, Москва 1998.

${ }^{19}$ Х. Арендт, Банальність зла. Суд над Айхманом в Срусалимі, пер. А. Ко те н ка, Київ 2013, c. 342.

${ }^{20}$ О. Чупа, Казки мого бомбосховища: роман, Харків 2015, с. 93. 
рваним на чолі та інших. Об'єднує їх тільки те, що мешкають в одному старому будинку - у сталінській чотириповерхівці, у типовому робітничому місті Донбасу. На кожному поверсі - три квартири. Загалом - дванадцять квартир, дванадцять інтригуючих оповідань, дванадцять історій — окремі люди, їхні родини, друзі, коханці й коханки, випадкові знайомі. Виходить цілком серйозний формат оповіді, незважаючи на “дрібнокаліберність" кожного з оповідань, що відображають долі сучасних маленьких людей зі Сходу України. Той факт, що роман не становить суцільний наратив, а складається зі шматків окремих персонажних історій, більш чи менш повних, хоча переважно таки фрагментарних, - може бути потрактовано або як наслідок недосвідченості автора, або як особливість твору, що вдало імітує роз'єднаність, роздробленість, ізольованість цього донецького анклаву та людей, що його замешкують. Це добре відображає екзистенційну самотність кожного 3 персонажів. Незахищеність, непевність і непрогнозованість, якої вони зазнають повсякчас, $є$ не тільки усвідомлена, а й інтуїтивно відчута. Адже живучи зовсім близько одне від одного, навіть в одній квартирі, ці люди нерідко лишаються цілком чужими й не знаходять спільної мови, як-от, бабця Клава зі своїм внуком-шибайголовою, або сім'я Задорожних, або пенсіонерка Ірина та ії внучка Оленка, або ж родина малого Влада. Як не парадоксально, ці близькі світи виявляються насправді дуже далекими й відчуженими, нерідко й ворожими та агресивними щодо інших. Усі вони, разом узяті, ніби окремі камінці в мозаїці, працюють на збірний образ Донбасу. Складається враження певного аутичного, обмеженого, загальмованого у своєму розвитку середовища, у якому із зовнішнього погляду нічого не відбувається, хоча зсередини його таки роз'їдають одвічні людські пристрасті, які нічим погамувати не можна. Метонімія першого вдало втілюється в незмінності інтер'єра, що несе на собі печать позірної стабільності й традиційності. Як-от у квартирі Ірини з розділу Острів: „У знайомій від дитинства залі царював незвичний [...] порядок. А поза тим - там нічого не мінялося від часів останнього ремонту, себто років уже близько тридцяти, коли не більше. Канапа, що стоїть тут від створення світу. Вузька провалена канапа, на якій спали іiі батьки і на якій одного літнього дня ще в попередньому помешканні зачали Ірину; та сама канапа, на якій потім і Ірина вперше пізнала чоловіка [...]. Книжкова шафа на всю стіну. [...] Письмовий стіл, що під час родинних свят бував столом святковим. У дні, коли сім'я не збиралася з якогось там приводу, він завжди стояв порожній. Ну, хіба що ваза з квіткою або щось таке могло його прикрашати. Але не більше. [...] Крісло, у якому ще Ірина, а потім іï донька Анна, а потім онука Оленка просиджували цілі свої дитинства"21.

Мінімум речей - iз максимальним смисловим наповненням, оскільки кожна 3 них пов'язана $з$ багатими спогадами прожитого життя. Типовий набір пересічної радянської квартири, що в'ївся в пам'ять як речовий образ цілої епохи - минулого, що проте не стало минулим, бо ним і надалі живуть так само, як користуються старими зужитими меблями. Проте онучка Ірини, зберігаючи позірну вірність родинним традиціям, живе зовсім іншими інтересами, приховуючи їх, а у світі її уяви присутні зовсім інші інтер'єри, речі й символи, ніж оті, із бабусиної квартири. Ухиляння від викликів життя не рятує героїв роману Казки мого бомбосховища, а навпаки - заганяє углиб власної депресії. Зрештою, запити переважно елементарні - вижити, часто за будь-яку ціну, хоч би й обманюючи інших, блефуючи. Наліт культури, раси, традиції при цьому вияв-

${ }^{21}$ Там само, с. 100-102. 
ляється дуже тонкою матерією, яка щоразу, тобто за кожного серйозного випробування, рветься. Тому-то це герої внутрішнього роздвоєння, душевного надламу. Вони одночасно перебувають у двох вимірах і намагаються (що є незмінним джерелом неврозів) поєднати непоєднуване. Одними намагаються здаватися, бо так їх виховувано, так привчено, так належить поводитись за звичаєм, а іншими є насправді. Абсолют споживацтва й задоволення потреб тіла — їхня релігія, тому вони охоче наслідують поведінку тих, хто може самовіддано віддаватися насолодам тілесності аж до екстатичності ${ }^{22}$. Та 3 іншого боку, екстаз тіла виявляється неможливим - чи то з огляду на матеріальний стан, чи то через старіння й немічність тіла; це створює напруження й колізію постійної невротичності донецької тотожності. За ілюстрацію може правити хоч би вчителька Ольга Микитівна, згадана вище Ірина або мама Владика (розділ Juli morning). Не вільні від подібної роздвоєності й молоді персонажі. Щоправда, вони самовизначаються швидше й радикальніше - готові на все, легко переступаючи моральні норми, чинячи злочини задля задоволення своїх потреб і насолод. На цьому, очевидно, відбилася зміна епохи й нові динамічні умови, у які потрапила країна.

Вимушена, але в чомусь також ностальгійно плекана, самоілюзорна ізольованість мешканців сталінського будинку, яких описує О. Чупа, - ніби своєрідна молекула всього Донбасу, що переживає та відчуває світ подібним чином. Тільки небагатьом (знаменно, що це закохана й замріяна, усупереч сірим будням, квіткарка Ру та оповідач, alter ego автора) удасться покинути цей глухий закуток та вдихнути життя на повну силу. Інші так і будуть метатися поміж крайнощів, чужих правил та істин, накинутих ззовні, неспроможні знайти своє властиве місце. Вони не в силах покинути свій маленький, але сяк-так обжитий простір (квартиру, дім, подвір'я), вимушені довічно в ньому перебиватися - до старості й смерті. Проте все-таки марять іншим життям - далеким, блискучим і щирим, жалкують про втрачені колись можливості вирватися з рідного загумінка.

Книжка Олексія Чупи з модельованою в ній свідомістю мешканців Донбасу може правити за добрий приклад тривалої колонізації регіону, що породив метастази та інерцію колоніальної свідомості. Ментальна роздвоєність персонажів роману відображає властиву невизначеність їхнього статусу — достатньо асимільованих упродовж колоніальної історії, але все ж не позбавлених сумнівів і задавнених образ. Гадаю, це наслідок своєрідного зависання поміж двома національними культурними моделями в смертельно небезпечному фортелі. Як відомо, Донбас ідентифікує себе з російською культурою, попри те, що був і залишається в ній явищем маргінальним. Не кажемо вже про культуру повсякденності, де навіть функціонування мови зраджує назагал невисокий рівень освіченості й самототожності. Українська культурна ідентичність, хай і була значною в попередніх поколіннях (чого варті хоча б імена донецьких шістдесятників Івана Дзюби, Василя Стуса, Івана Світличного, Олекси Тихого та ін.), сьогодні виглядає цілковито пригніченою й дискримінованою. Дві культурні моделі, протилежні за семантикою (особливо тепер, в умовах фактичної війни двох країн) викликають роздвоєність і відчай у головах мешканців донецького краю. Адже вони „створюють радикально відмінні дискурси національного: постімперської меланхолії і стійкої спадщини теорії Достоєвського про «всесвітню сприйнятливість», з одного боку, і реконструювання та переоцінювання колоніального

${ }^{22}$ Z. B a uman, ibidem, s. 91. 
й до колоніального минулого, 3 другого"23. Принципова непоєднуваність цих моделей проектує роздвоєність донецької регіональної ідентичності не тільки в наш час, а й на майбутнє, принаймні на найближчі десятиліття.

Розв'язка роману представляє властивий “ісход” мешканців Донбасу, що вимушені покидати свої місця в умовах війни. Це категорична межа, що ділить життя героїв навпіл - на “до” і “після”. І проектувати її випадає на широке соціальне тло, адже 2014 рік обернувся драматичним надламом у долі мільйонів мешканців східноукраїнських теренів. Про це ще будуть багато говорити й писати. Бо явище безпрецедентне й варте увічнення у слові. Відомо, що покидати родинні місця завжди боляче, тим більше, коли це роблять не добровільно, а під тиском обставин. Вимушене вигнання, разом з тим, стає тим чинником, який, урешті, таки мобілізує свідомість і творить з розрізнених, атомованих “я" колективне "ми", яке прагне знайти свій голос.

Досвід локальної ідентичності, який у цій статті представлено на прикладі роману Олексія Чупи Казки мого бомбосховища, прикметний у багатьох смислах. По-перше, він засвідчує дуже серйозний і досі не врахований backgroundimage, що постає із тривалої практики колоніалізму та має з нею досі органічний зв'язок. По-друге, визначимо, що період незалежної України для Донбасу виявився періодом стагнації й цивілізаційного “зависання": саме через те старі імперські міфи не були розвінчані й досі мають вплив на мешканців регіону. По-третє, останні події стали мобілізаційним чинником, що спонукає до більш активного становлення локальної ідентичності донеччан, а також до однозначного вибору в умовах воєнного конфлікту (такого вибору раніше їм вдавалося уникати, лавіруючи поміж різними політичними та світоглядними орієнтаціями). Цей останній фактор дає надію, що ситуація надалі буде змінюватись значно швидше й динамічніше, ніж досі.

Вироблення колективної ідентичності апелює заразом і до типової екзистенційної ситуації, що супроводжується переоцінкою цінностей, і до зміни суспільної матриці сприймання людини як соціальної істоти. Герої роману О. Чупи Казки мого бомбосховища тяжіють або до аскетичного, або ж до гедоністичного переживання власних тілесних бажань. Наближення до продуктивного й креативного рівня роботи з бажанням виглядає для них ще не досяжною перспективою. Однак відхід від безпосередньої, біологічної тілесності в бік осмисленої, соціалізованої вже сам по собі є маркером еволюції. Саме на цьому характерному процесі ми й прагнули концентрувати увагу в межах цієї статті.

${ }^{23}$ В. Чернецький, Картографуючи посткомуністичні культури. Росія та Украӥна в контексті глобалізації, а в то р изо ван и й пер. $з$ англ., Київ 2013, с. 388. 